\title{
How have environmental concepts reshaped the agroforestry concept?
}

Marie BARISAUX ${ }^{1,2}$

${ }^{1}$ AgroParisTech

16 rue Claude Bernard

75005 Paris

France

\section{${ }^{2}$ Cirad}

UPR Forêts et Sociétés

Campus International de Baillarguet 34398 Montpellier cedex 5 France

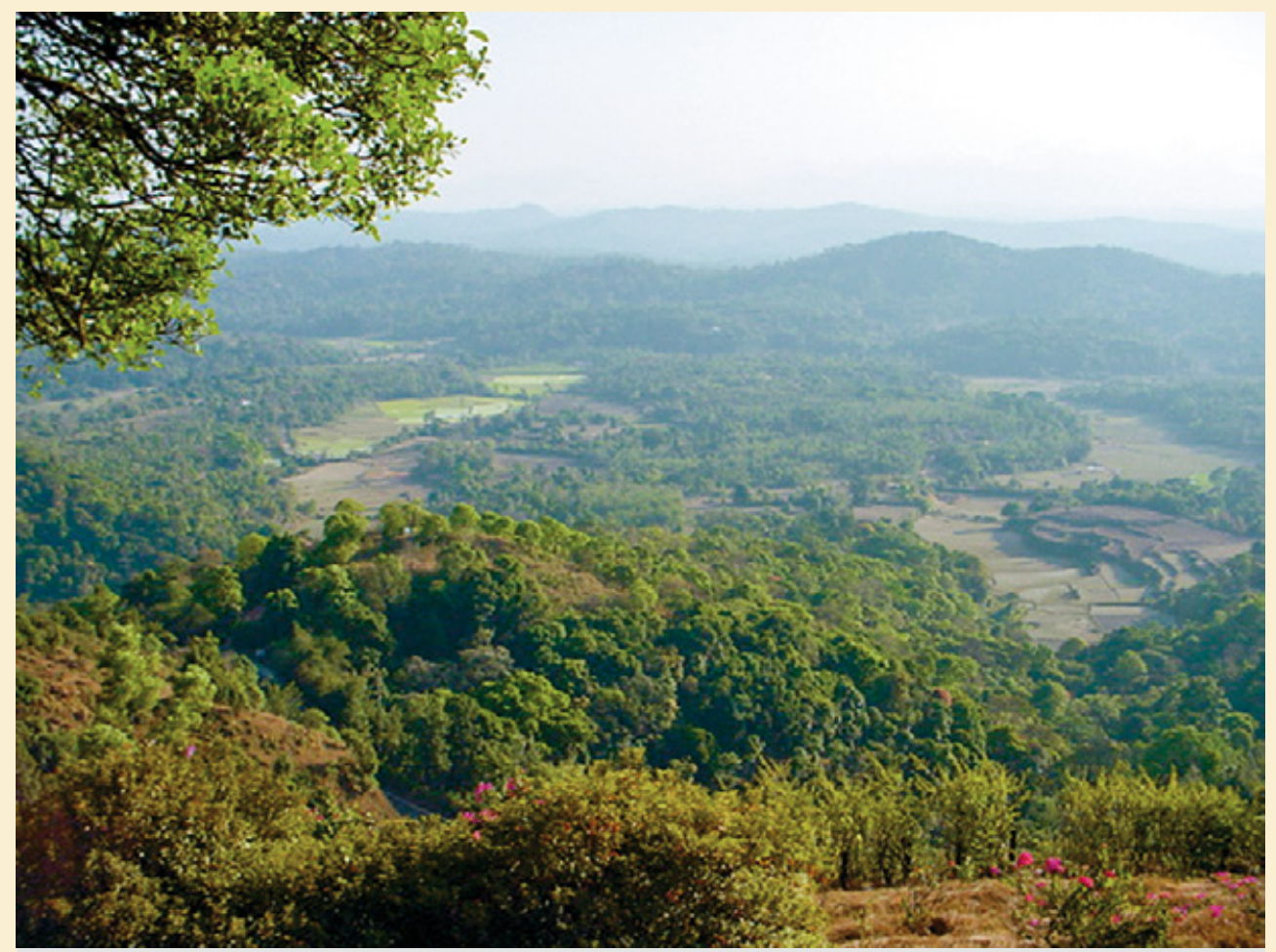

Photo 1.

Landscape of Kodagu in the South-West Ghats of India (State of Karnataka).

Rice fields alternate with coffee plantations under forest shade. In the background, the natural forest massif. Forests are intertwined in coffee plantations.

Photo. C. Garcia. 


\section{RÉSUMÉ}

\section{COMMENT LES CONCEPTS ENVIRONNEMENTAUX ONT- ILS REFAÇONNÉ LE CONCEPT AGROFORESTIER ?}

Les trois dernières décennies ont été les témoins d'une évolution des sciences et des concepts environnementaux. Le but de cet article est de rendre compte de cette évolution et de montrer ses conséquences sur le concept agroforestier. Il repose sur une analyse bibliométrique réalisée via le Web of Science, et dresse une synthèse de la littérature recueillie sur le sujet. Des exemples sont évoqués pour appuyer l'argumentation : le système agroforestier du café dans la région des Western Ghats en Inde, le système agroforestier du cacao en Côte d'Ivoire et le système agroforestier de l'hévéa (jungle rubber) en Indonésie. L'agroforesterie a considérablement évolué avec l'avènement des notions de biodiversité et d'écosystèmes émergents, et la science de la conservation englobe maintenant les écosystèmes modifiés et altérés par l'homme. L'évolution de l'agroforesterie peut ainsi être comparée avec celle de l'agroécologie : une étude à partir du Web of Science montre une évolution similaire sur les deux dernières décennies. La reconnaissance de l'agroécologie en tant que science a apporté de nouvelles méthodes de gestion des systèmes agroforestiers. Cependant, l'agroforesterie, par son évolution et par l'étendue du concept, est peut-être restée trop déconnectée de la réalité du terrain et des paysans qui la pratiquent. Des précautions dans la conception et la gestion de ces systèmes doivent donc être prises : il s'agit de ne pas oublier les attentes des paysans dans des contextes et avec des déterminants à la fois sociaux, économiques et politiques ; ni de s'orienter vers des systèmes exclusivement productivistes. L'agroforesterie ne saurait devenir un concept environnemental si elle se vide de sa substance authentique, vouée à l'amélioration durable du bien-être des paysans.

Mots-clés : agroforesterie, environnement, biodiversité, agroécologie, conservation, paysan.

\section{ABSTRACT}

\section{HOW HAVE ENVIRONMENTAL CONCEPTS RESHAPED THE AGROFORESTRY CONCEPT?}

Environmental sciences and concepts have evolved a great deal in the last three decades. This study aims to account for the way environmental concepts have changed and to describe the consequences for the concept of agroforestry. The study is based on a bibliometric analysis carried out on the Web of Science, and summarizes the literature collected on the subject. Examples are given to support the analysis: agroforestry-based coffee-growing in the Western Ghats in India, cocoa in Ivory Coast and jungle rubber in Indonesia. Agroforestry evolved considerably with the emergence of the biodiversity and ecosystem concepts, and conservation science now also covers ecosystems that have been modified by humans. The development of agroforestry can be compared with that of agroecology: a study on the Web of Science shows a similar pattern in the last two decades. Although the recognition of agroecology as a science has introduced new ways of managing agroforestry systems, the way agroforestry has developed and its broad scope of application may have disconnected it somewhat from reality on the ground and from the farmers who actually practice it. Precautions are therefore needed in designing and managing these systems: farmers' expectations, in contexts that are determined at once by social, economic and political factors, must not be ignored, and agroforestry systems should not be exclusively geared to productivity. Agroforestry cannot evolve as an environmental concept if it is voided of its most fundamental goal, which is to bring sustainable improvements to farming livelihoods.

Keywords: agroforestry, environment, biodiversity, agroecology, conservation, smallholder.

\section{RESUMEN}

\section{¿CÓMO LOS CONCEPTOS AMBIENTALES HAN REMODELADO EL CONCEPTO AGROFORESTAL?}

En las tres últimas décadas se ha producido una evolución de las ciencias y conceptos ambientales. El objetivo de este artículo es dar cuenta de esta evolución y mostrar sus consecuencias en el concepto agroforestal. Se basa en un análisis bibliométrico realizado a partir de la Web of Science y resume la bibliografía recopilada sobre el tema. Se mencionan ejemplos para sustentar el análisis: el sistema agroforestal con café en la región de Western Ghats en la India, el sistema agroforestal con cacao en Costa de Marfily el sistema agroforestal con caucho (jungle rubber) en indonesia. La agroforestería ha evolucionado considerablemente con la aparición de las nociones de biodiversidad y ecosistemas emergentes, y la ciencia de la conservación abarca ahora los ecosistemas modificados y alterados por el ser humano. Así pues, la evolución de la agroforestería y de la agroecología pueden compararse: un estudio basado en la Web of Science muestra una evolución similar en las dos últimas décadas. El reconocimiento de la agroecología como ciencia ha traído nuevas formas de manejo para los sistemas agroforestales. Sin embargo, la agroforestería, por su evolución y por la amplitud del concepto, permaneció quizás demasiado desconectada de la realidad de campo y de los campesinos que la practican. Es preciso adoptar precauciones en la concepción y manejo de dichos sistemas: no se deben olvidar las expectativas de los campesinos en unos contextos y con unos determinantes, a la vez, sociales, económicos y políticos; ni dirigirse hacia sistemas únicamente productivistas. La agroforestería no podrá convertirse en un concepto ambiental si se desprende de su principal aspecto, destinado a mejorar de modo sostenible el bienestar de los campesinos.

Palabras clave: agroforestería, medio ambiente, biodiversidad, agroecología, conservación, campesino. 


\section{Introduction}

During the last three decades, our vision of nature and environment evolved considerably. The wilderness and the concept of a pristine nature have been dismissed with this evolution, and biodiversity became the standard for conservation science. Conservation and environmental sciences became therefore larger, incorporating all ecosystems in the whole territory. This means also human-modified and human-altered ecosystems, such as agroecosystems. This evolution of the environmental concepts answers to an evolution of the society, to which environment is becoming more and more meaningful (Kareiva et al., 2012; Larrère and Larrère, 2015).

Agroforestry systems can therefore be seen within this dynamic, as an agroecosystem which can play a role in biodiversity conservation and which can provide ecosystem services for ameliorated food production, social and environmental benefits. Agroforestry is a technique practised by farmers for centuries, but it appears that it became a widespread concept quite recently.

Acknowledging these realities, this article is an attempt to understand how agroforestry evolved by incorporating environmental concepts, and questions if this incorporation was compatible with the farmers' expectations.

\section{Problem and research questions}

\section{Evolution of agroforestry definitions}

The consideration of environment within agroforestry evolved with its definitions. The very first one was suggested in 1977 by the Research Center for International Development (IRDC, Canada). It presented agroforestry as "a sustainable management system for land that increases overall production, combines agricultural crops, tree crops, and forest plants and/or animals simultaneously or sequentially, and applies management practices that are compatible with the cultural patterns of the local population" (Bene et al., 1977). Another definition was provided by the World Agroforestry Center (ICRAF) in 1982: agroforestry was "a collective name for landuse systems and technologies where woody perennials (trees, shrubs, palms, bamboos etc.) are deliberately used on the same land-use management units as agricultural crops and/ or animals, in some form of special arrangement or temporal sequence. In agroforestry systems there are both ecological and economical interactions between the different components" (Lundgren and Raintree, 1983). The World Agroforestry Center finally updated its definition of agroforestry in 2000. It became then "a dynamic, ecologically based natural resource management practices that, through the integration of trees and other tall woody plants on farms in the agricultural landscape, diversifies production for increased social, economic and environmental benefits" (Schroth et al., 2004).

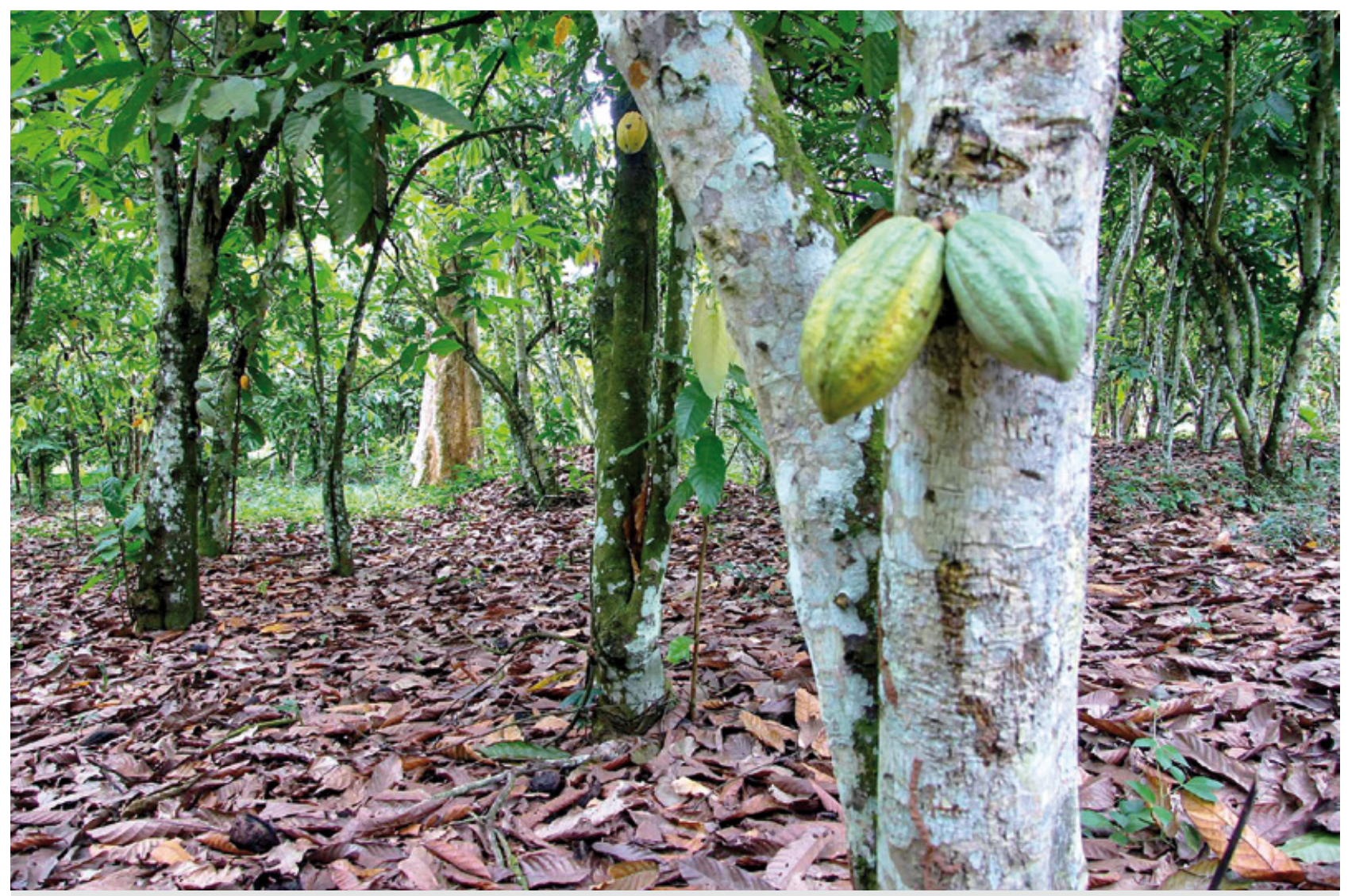

Photo 2.

Smallholder cocoa plantation in the shadow, under some trees of the original forest in the Azopé region, East of Côte d'Ivoire. Photo D. Louppe. 
Definitions evolved from a mainly agricultural approach in 1977 towards a more and more significant recognition of the environmental part. The latter definition also involved the social and economical sciences within agroforestry.

\section{Research questions}

This recognition of environmental sciences within the definitions of agroforestry in the past thirty years leads to several questions, which we will try to answer in this article: - How have agroforestry integrated this evolution of environmental concepts?

- Was this integration compatible with farmers' expectations?

\section{Materials and methods}

\section{Bibliometric analysis on the Web of Science}

We utilized the research platform Web of Science for this bibliometric analysis because it's very comprehensive and versatile, and covers a very large number of disciplines in all types of publications. Therefore, an analysis on this platform gives a good overview of the total number of studies realized for different subjects.

The aim of this bibliometric analysis is to have an idea of the share of different topics within agroforestry research.

\section{Evolution of environmental topics within agroforestry research}

The aim of this part of the study was to show if agroforestry evolved towards a more significant recognition of its links with environmental sciences over time. We tried to define environmental sciences by using different keywords, to encompass the largest number of studies. We chose the words "environment", "ecology" and "biodiversity". Results give the number of entries found within the topic. We then classified

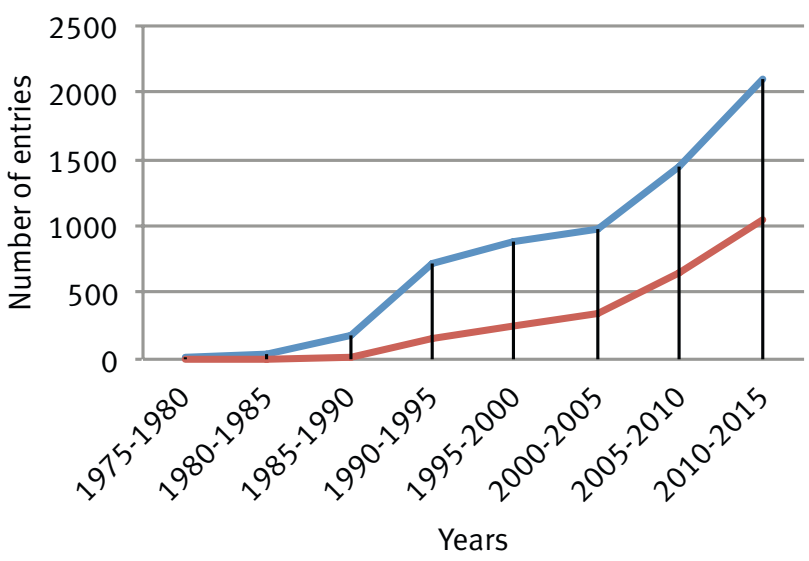

Agroforestry $\quad$ Agroforestry AND environmental topics

Figure 1.

Number of entries of agroforestry dealing or not with environmental topics, from 1975 to 2015. Study realized on the Web of Science. the number of studies every five years between 1975 and 2015 by using the simple commands on the Web of Science:

- [(agroforestry*) AND (environment* OR ecolog* OR biodiversity $\left.\left.{ }^{\star}\right)\right]$

- [(agroforestry $\left.\left.{ }^{\star}\right)\right]$

Results are presented in figure 1.

\section{Evolution of environmental topics within agroecological research}

The aim of this part of the study was to compare the evolution of environmental topics within agroecological research with the results obtained in figure 1 . We used the same keywords to definite the main topics and made the following requests on the Web of Science every five years between 1975 and 2015:

- [(agroecolog* OR agro-ecolog*) AND (environment* OR ecolog* OR biodiversity*)]

- [(agroecolog* OR agro-ecolog*)]

Results are presented in figure 2.

\section{Evolution of socio-economical topics within agroforestry research}

The aim of this part of the study was to show the relative importance of socio-economical topics in comparison to agricultural and environmental topics within agroforestry research. We used different keywords to definite each topic, trying to encompass the largest number of studies. We chose the words "agriculture", "yield", "crop" and "livestock" for the agricultural topic, and the words 'society' and "economic" for the socio-economical topic. The following requests were made every five years between 1975 and 2015:

- [(agroforestry*) AND (environment* OR ecolog* OR biodiversity $\left.\left.{ }^{\star}\right)\right]$

- [(agroforestry*) AND (agricultur* OR yield* OR crop* OR livestock*)]

- [(agroforestry*) AND (societ* OR econom*)]

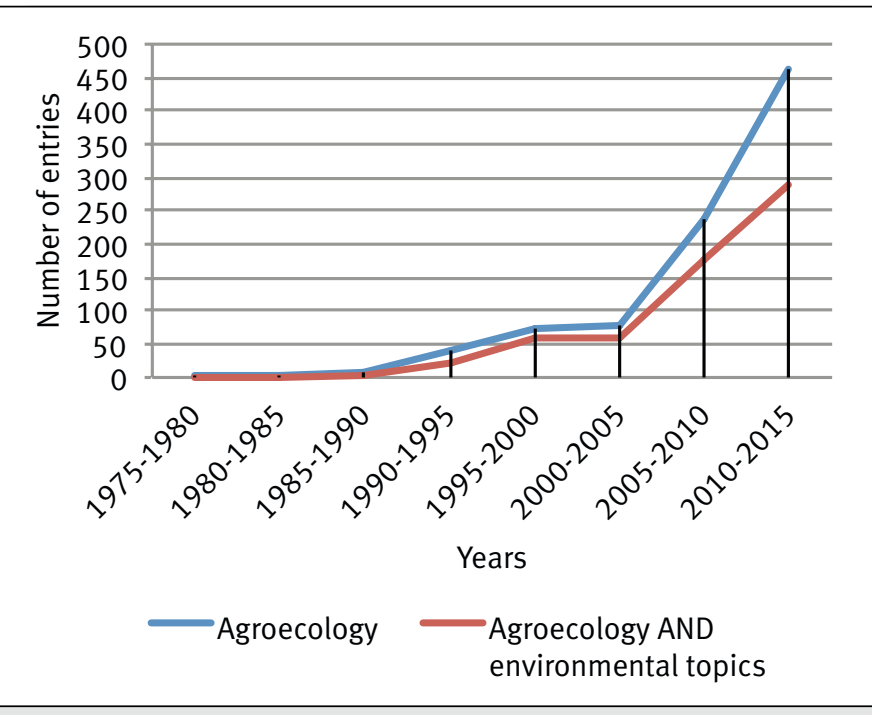

Figure 2.

Number of entries of agroecology dealing or not with environmental topics, from 1975 to 2015. Study realized on the Web of Science. 
We made then a comparison of the relative importance of these topics within agroecological research. The following requests were made every five years between 1975 and 2015:

- [(agroecolog* OR agro-ecolog*) AND (environment* OR ecolog* OR biodiversity*)]

- [(agroecolog* OR agro-ecolog*) AND (agricultur $^{\star}$ OR yield* OR crop* OR livestock $\left.{ }^{\star}\right)$ ]

- [(agroecolog* OR agro-ecolog*) AND (societ* OR econom*)] and 4.

Results are presented in figures 3

\section{Application of this integration of environmental topics for farmers}

The aim of this part of the study is to measure the application degree of agroforestry research for farmers. For that, we just retook the precedent requests and added a constraint about farmers, by using the keywords "smallholder" and "farmer". We then made the following request on the Web of Science every five years between 1975 and 2015:

- [(agroforestry*) AND (environment* OR ecolog* OR biodiversity*) AND (smallhol-

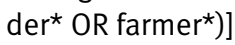

Another analysis can be made by classifying the number of studies by country, in order to determine if there are areas in which research is more or less focused on environmental sciences for farmers. All tropical countries were tested and then regrouped in large areas: North America, Central America, South America, North Africa, West Africa, Central Africa, East Africa, South Africa, South Asia and South-East Asia. The goal was also to determine if there are areas where agroforestry research is under-represented. The following requests were made:

- [(agroforestry*) AND (environment* OR ecolog* OR biodiversity*) AND (smallhol-

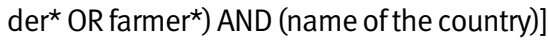

Results are presented in figures 5 , 6 and 7.

\section{Case study review}

Agroforestry systems are not anymore seen as only agricultural systems, but as complex food systems in which environmental sciences are preponderant. Agroforestry systems are therefore managed in an eco-friendly way and are able to bring environmental services, such as carbon sequestration, soil enrichment, air and water quality and biodiversity

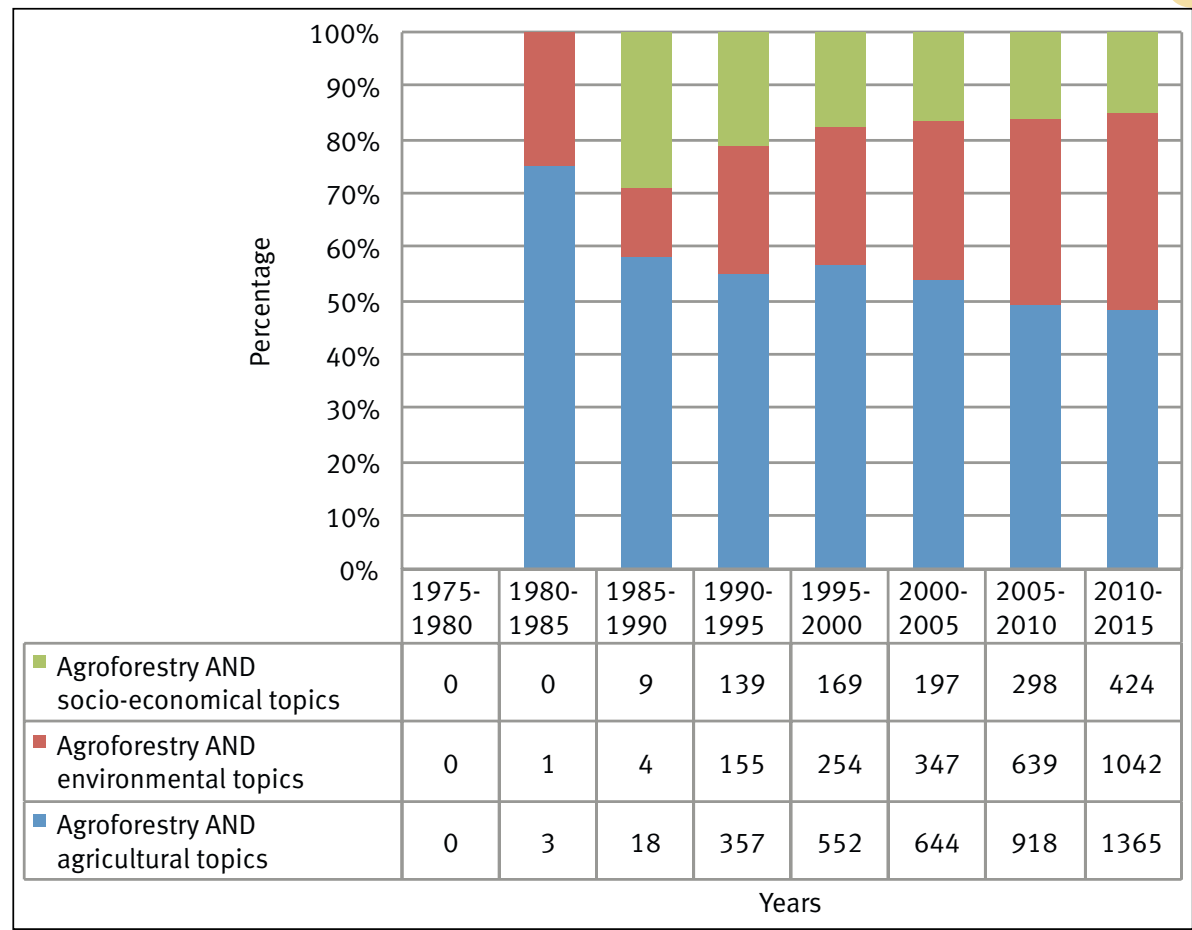

Figure 3.

Share of agricultural, environmental and socio-economical topics in agroforestry research: percentage of the number of studies of each domain coupled to agroforestry research with respect to the total number of studies involving agroforestry, between 1980 and 2015. Study realized on the Web of Science.

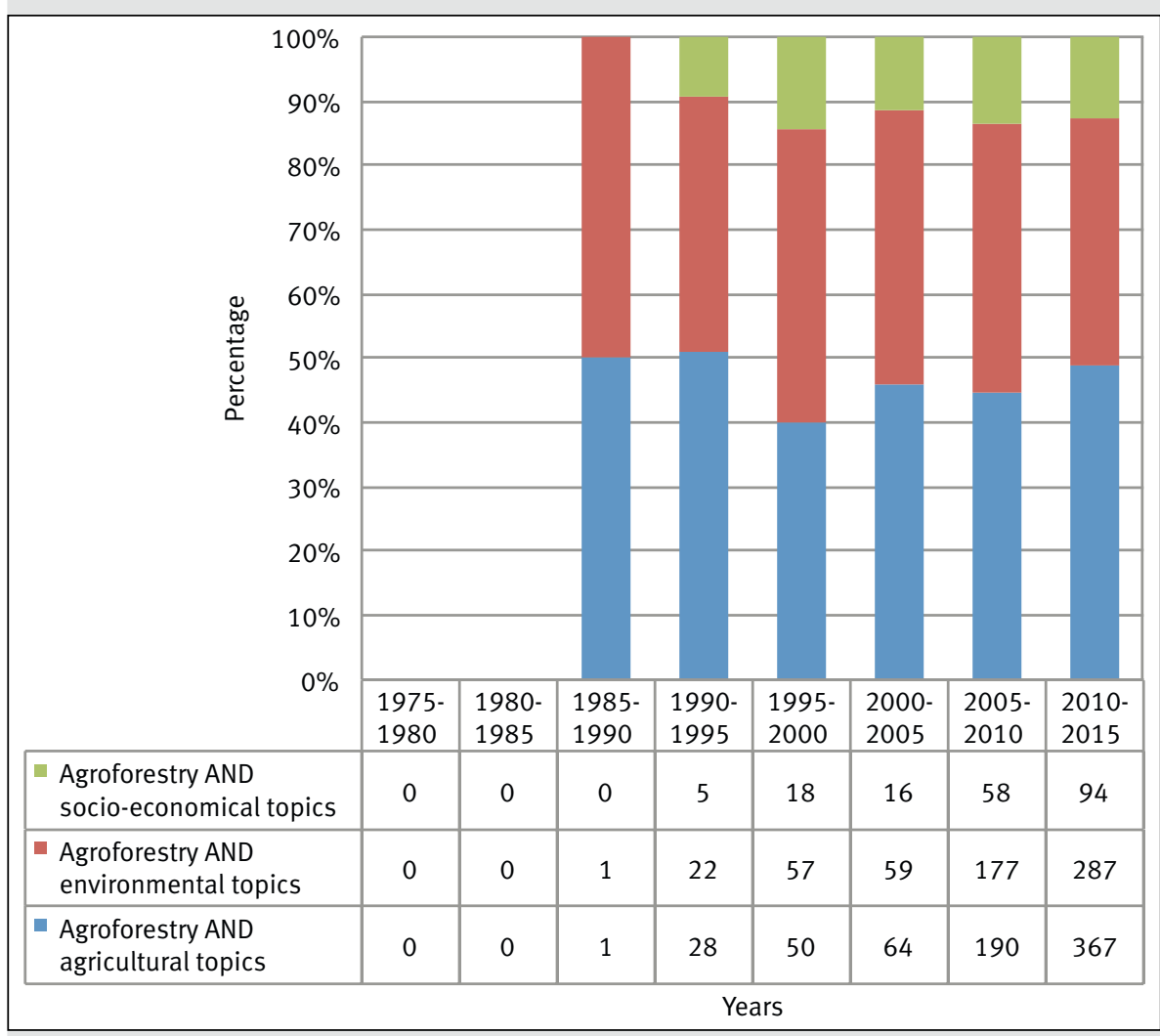

Figure 4.

Share of agricultural, environmental and socio-economical topics in agroecological research: percentage of the number of studies of each domain coupled to agroecology research with respect to the total number of studies involving agroecology, between 1985 and 2015. Study realized on the Web of Science. 


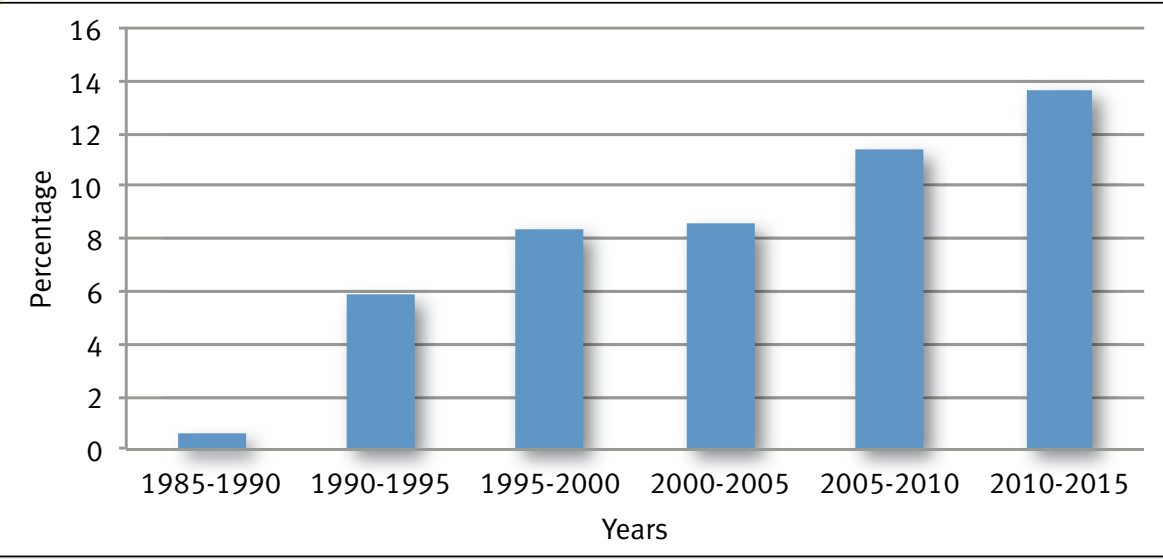

Figure 5.

Share of environmental topics coupled with farmers in agroforestry research between 1985 and 2015. Study realized on the Web of Science.

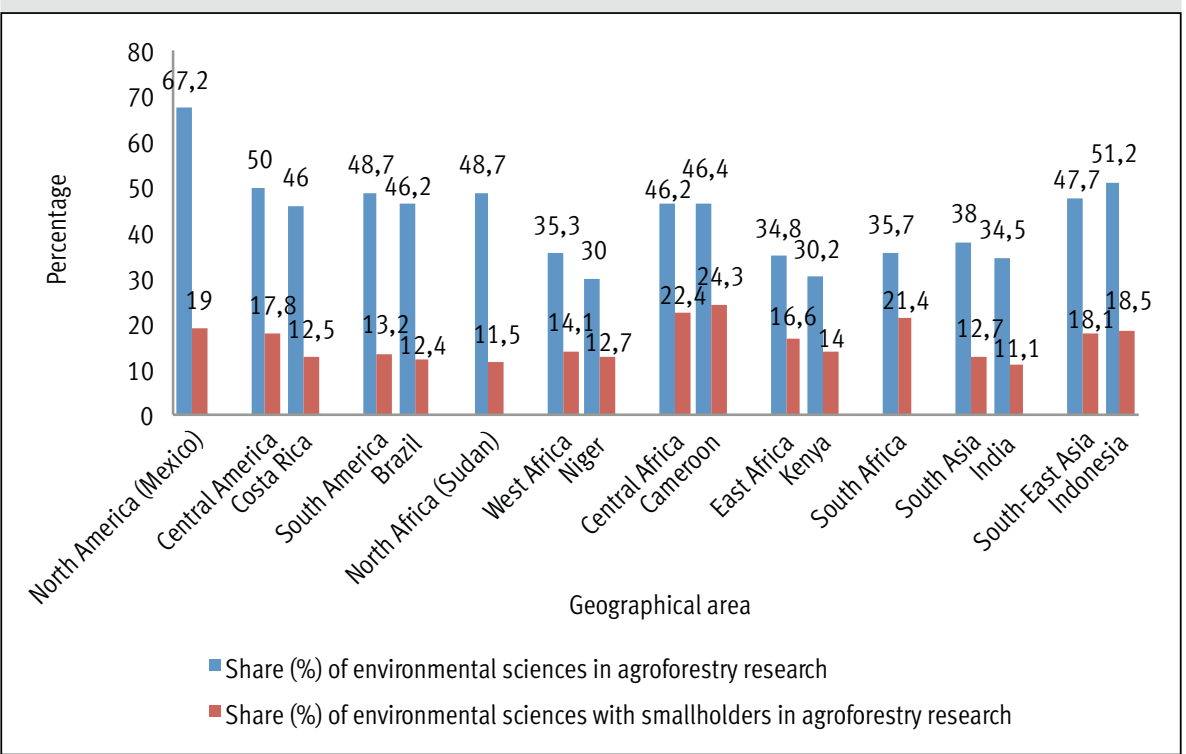

Figure 6.

Share of environmental topics and of environmental topics coupled with farmers in agroforestry research.

Study realized on the Web of Science.

We decided to work on three examples to support the analysis. The chosen examples are the coffee agroforestry system in the Western Ghats in India, the cocoa agroforestry system in Côte d'Ivoire and the jungle rubber of Indonesia. We chose those examples because they are attesting this recognition of environmental and conservation issues in agroforestry, and because of the profuse literature found on these examples. They are used to attest how this integration of environmental concepts is happening on the field, and to determine if there are limits in its application.

\section{RESULTS}

\section{Bibliometric analysis}

\section{Evolution of environmental topics within agroforestry research}

Environmental sciences within agroforestry systems are becoming increasingly meaningful in research, especially for the last two decades. Figure 1 shows this trend: we notice an increase of the red curve's slope, which means an acceleration of the importance of environmental topics within agroforestry research. Indeed, its proportion of environmental topics coupled with agroforestry research in the Web of Science evolved from about 30\% between 1995 and 2000 to $50 \%$ between 2010 and 2015 (figure 1). Indeed, since 2000, environmental topics are increasingly important in agroforestry research. This was a consequence of the 1992 Rio Summit's Convention on Biological Diversity. It bought a political obligation for the preservation of biodiversity, and thus the creation of an international program for biodiversity research (1991). Assessments such as The Global Biodiversity Assessment

conservation (Jose, 2009). A particular interest is paid to the conservation of biodiversity. Indeed, most of tropical landscapes are characterized by a mosaic of remnants primary forest fragments, secondary forest patches, small farms and large monocultural plantation areas (Perfecto and Vandermeer, 2008). Agroforestry systems within these landscapes can play a role in biodiversity conservation through different ways: three hypotheses were made by Schroth et al. (2004). The agroforestry-deforestation hypothesis is based on the assumption that agroforestry can reduce the deforestation pressure on additional land; the agroforestry-habitat hypothesis assumes that agroforestry systems can provide habitats for local species; and the agroforestry-matrix hypothesis states that agroforestry systems can promote connectivity between different forest patches (Schroth et al., 2004).
(1993) and the Millennium Ecosystem Assessment (2001) were also launched. More recently Consortiums such as the Intergovernmental Platform on Biodiversity and Ecosystem Services (IPBES) were established (2012). Such an evolution has resulted in reshaping the agroforestry concept (Larrère and Larrère, 2015).

\section{Evolution of environmental topics within agroecological research}

Figure 2 indicates the number of entries found in the Web of Science of agroecology dealing or not with environmental topics. The red curve shows that environmental topics are extremely meaningful in agroecological research: more than half of the studies encountered are mentioning at least 


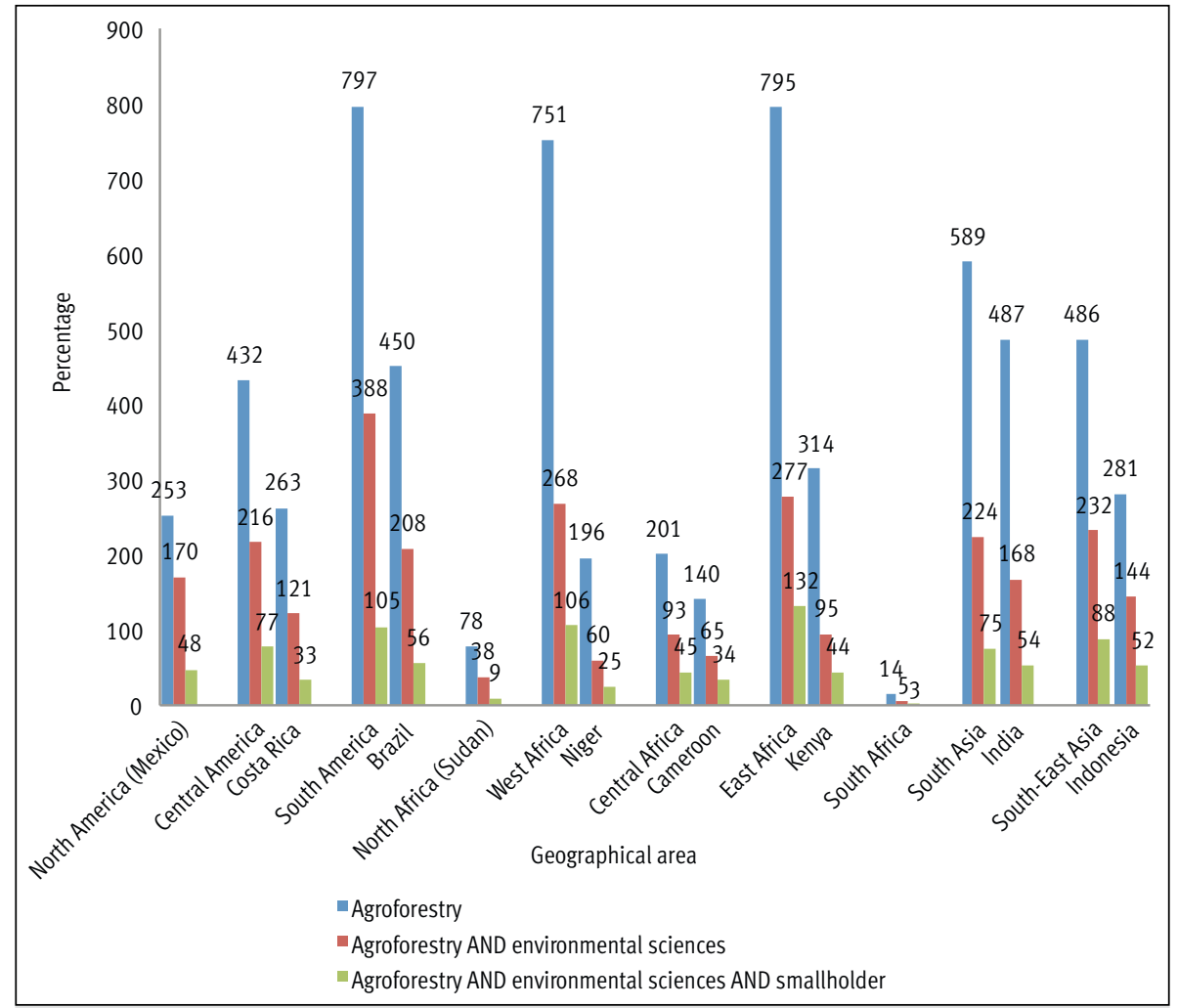

Figure 7.

Number of studies in agroforestry research coupled or not with environmental topics, and with environmental topics and farmers. Study realized on the Web of Science.

are present in agroforestry research since 1990, but their share is quite low and apparently constant: about $15 \%$. This low relative importance of these socio-economical topics within agroforestry research is surprising considering the social importance of agroforestry, which is technique practised by farmers for centuries. The evolution of these three different domains in agroforestry research can be copying with the evolution of the definitions of agroforestry, in which the accession of environmental and socio-economical topics are observed in the same period of time.

By comparing figures 3 and 4, we notice that the share of each domain within agroforestry and agroecological research is quite the same since 2000. Shares of agricultural topics and environmental topics are almost the same, and shares of socio-economical topics are about $15 \%$.

\section{Application of this integration of environmental topics for farmers}

The aim of this part of the study was to measure the application degree of the influence of environ-

one of the topics. Moreover, agroforestry and agroecological research have the same highly increasing activity since 2000 (figures 1 and 2). However, the number of agroecological studies was low compared to that of agroforestry whereas both are widespread concepts: about 450 studies for agroecological research between 2010 and 2015, and about 2100 for agroforestry research in the same period of time. Agroecology is indeed a recent science, whereas agroforestry is ancient and practiced by many farmers around the world, which explains its importance (Wezel et al., 2009).

\section{Evolution of socio-economical topics within agroforestry research}

The aim of this part of the study was to establish the relative importance of socio-economical topics compared to agricultural and environmental topics in agroforestry research (figure 3 ). We made then a comparison with agroecological research (figure 4).

The proportion of socio-economical topics in agroforestry research seemed significant between 1985 and 1990 but it should be seen with considering the low number of studies. Moreover, those studies were mainly focused on the economical aspect until 2000. The proportion of environmental topics is on a constant increase since their first appearance: from $10 \%$ between 1980 and 1985 to almost $40 \%$ between 2010 and 2015. Socio-economical topics mental topics in agroforestry research. In figure 5 we note that the share of environmental topics coupled with farmers in agroforestry research is in constant evolution since 1985 but is still quite low: only $13 \%$ of the studies realized between 2010 and 2015 contain the word "smallholder" or "farmer". Application of this evolution of agroforestry for farmers seems therefore not so important.

In figures 6 and 7, we classified the number of studies by country, in order to determine if there are areas in which research is more or less focused on environmental topics and farmers. For each area, the country with the largest number of studies focused on agroforestry was identified. In the cases of North America, North Africa and South Africa the number of tropical countries was low: only Mexico and Soudan for North America and North Africa, and Namibia and Botswana for South Africa. These areas were not taken into account in our analysis due to their poor representativeness. Areas in which the share of environmental topics was the lowest in agroforestry research were clearly West Africa and East Africa, whereas the number of studies was one of the highest (third and first respectively). Areas in which the share of environmental topics was the greatest were America and South-East Asia. The total number of studies is not so important in these areas, but their surface areas are a lot lower than the other ones. Their relative significance is therefore very high. 
When adding the "farmer constraint", the lowest percentages were found in Central Africa and South-East Asia. However this result should be balanced with the total number of studies realized for Central Africa: it presents the lowest number of studies and $70 \%$ were in Cameroon. In the case of South-East Asia, we can argue that the expansion of intensive systems such as palm oil is made at the expense of smallholders (Rist et al., 2010).

\section{Case study review}

\section{Coffee agroforests in the Western Ghats, India}

India is the fifth producer of coffee: it represents $4 \%$ of the world total production. The Western Ghats, situated in the south of India, represent a third of this production, driven by coffee agroforestry systems (Garcia et al., 2009).

The Western Ghats are a mosaic of different components: forests, coffee estates and other crops; forming a multifunctional landscape. This region is considered as a biodiversity hotspot (Ambinakudige and Sathish, 2008). Forests represent almost $50 \%$ of this landscape, and coffee estates about $30 \%$. They play a very important role in biodiversity conservation by acting as biological corridors in this landscape, promoting connectivity between different patches of forest. With the forest remnants, coffee estates also offer a wide variety of environmental services, such as pollination, carbon sequestration and water recharge (Schroth et al., 2004; Garcia et al., 2007; Anand et al., 2010).

Coffee in Western Ghats is traditionally grown under native trees to shade the coffee trees during the dry season. Benefits of shade coffee are indeed well recognized, and many efforts have been made to promote its ecosystem services, like the CAFNET project (Kushalappa et al., 2014). But in the last two decades, the traditional cultivation of Arabica coffee was replaced by Robusta coffee, which has a better pest control and an easier management. Moreover, modernization and massive development of irrigation systems and chemical fertilizers have made farmers less dependent on the canopy cover and its environmental services. In a goal of increased yields, native species have been substituted by the fast-growing exotic Silver grevillea (Grevillea robusta): this specie is indeed easily marketable because it is not submitted to the complicated administrative path to which farmers have to comply in order to fell and sell a tree. Grevillea robusta is therefore becoming highly widespread in these coffee agroforestry systems at the expense of native trees even valuable timber species - and biodiversity (Garcia et al., 2009). Farmers' knowledge concerning the techniques and the trees they can use in coffee agroforestry systems isn't therefore taken into account: political and administrative barriers incite them to abandon native species for Grevillea robusta.

In Western Ghats, a strategy for integrating agricultural landscapes with biodiversity conservation promoted by Harvey et al. (2008) was examined by Garcia et al. (2009). This strategy was based on six points, which are: $i$ ) identify and prioritize rural hotspots; ii) identify and mitigate key threats to biodiversity; iii) conserve remaining forest habitats; iv) protect, diversify and sustainably manage tree cover; $v$ ) promote and conserve traditional ecologically based agricultural practices; and vi) restore degraded land through reforestation or natural regeneration (Harvey et al., 2008). But promoting biodiversity in this complex landscape can be complicated due to the diversity of people, groups and corporations: find a common ground can therefore be complex (Garcia et al., 2009). Conservation efforts should be made integrating farmers' aspirations. Economic benefits are the main reason why farmers turn to intensive systems, that's why promoting payment for ecosystem services and eco-friendly labels should be developed (Garcia et al., 2007; Marie-Vivien et al., 2014). A sustainable agroforestry system has therefore to integrate the social and economical farmers' expectations.

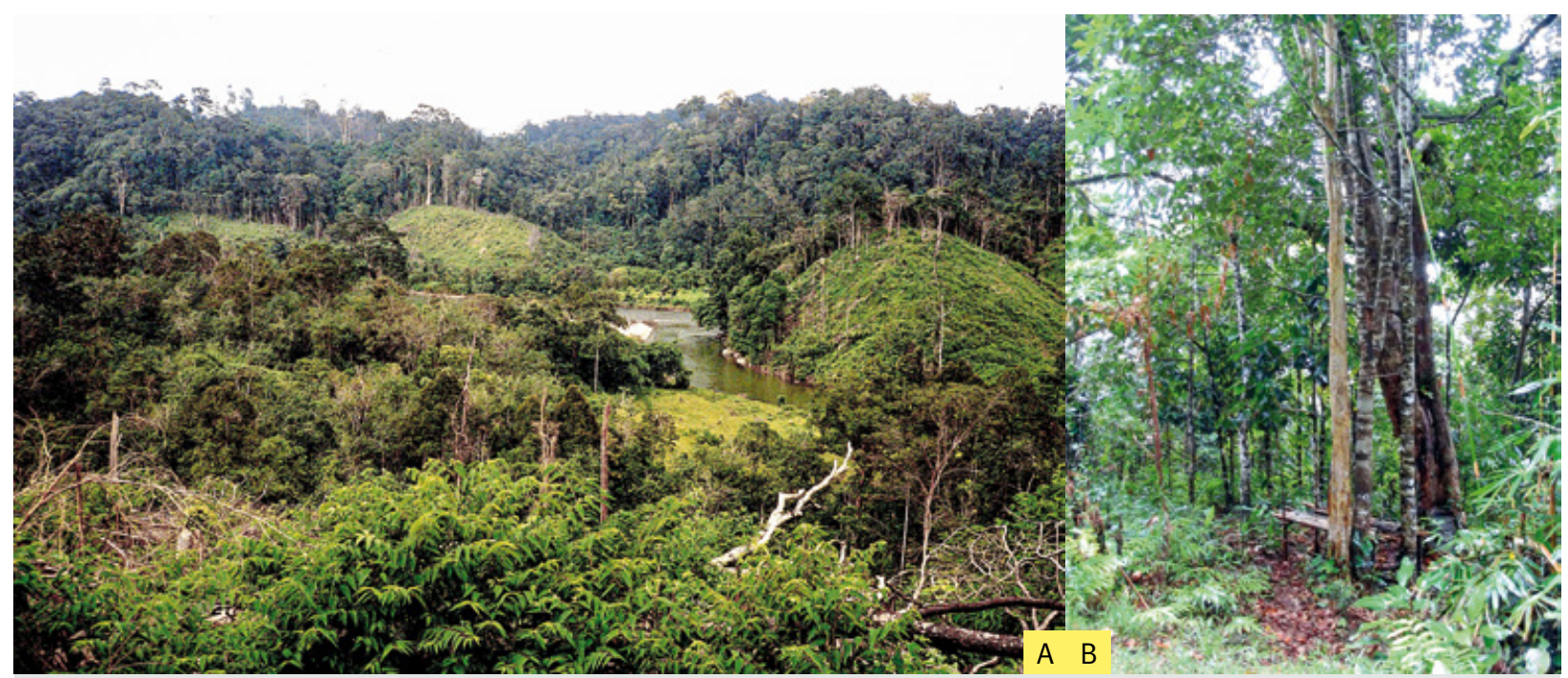

Photo 3.

A. Jungle Rubber landscape, with clearing of forest and Rubber trees inside the forest, near Jampi on Sumatra Island in Indonesia. B. Inside of a Jungle Rubber in Indonesia with:

- Hevea brasiliensis (Rubber tree), cultivated for his great industrial valour of latex, and later for woodfuel;

- Palaquim gutta (Guta tree or Sap tree), cultivated great industrial valor to produce rigid natural latex;

- Artocarpus heterophyllus (Jackfruit tree or Bread tree), cultivated for his big production of edible fruits and for his precious yellow wood);

- Lansium domesticum (Duku tree or Langsat tree), producing edible fruits and the wood used in building for its good properties of hardness, thickness and resilience.

Photo E. Penot. 


\section{Cocoa plantations in Côte d'Ivoire}

Since the late 1970s, Côte d'Ivoire is the first producer of cocoa. Its production is based on the forest income consumption (Ruf, 1997). This forest income is nowadays almost over and cocoa plantations cannot feed themselves on it. Indeed, the depletion of forest resources makes it unable to give the necessary environmental services for cocoa production: declining yields, due to low fertility and pest and diseases problems are therefore observed (Dumont et al., 2014; Sanial, 2015).

The introduction of trees within cocoa plantations to create agroforestry systems was therefore promoted. Several environmental services can be brought through trees, such as shade, pest and diseases control and water retention (Duguma et al., 2001). Cocoa agroforestry would therefore permit the renewal of the forest income and a sustainable production (Sanial, 2015).

To promote these agroforestry systems, different strategies have been established. One was the creation of cooperatives, which can advice producers on the different techniques and trees to establish in their plantations. But cooperatives and their "official" knowledge can differ from the farmers' knowledge. Strong incentives are given to farmers for the establishment of agroforestry systems, but the tree species they recommend are often exotic species such as Acacia manguium and Gliciridia sepium. Moreover, some species actually used within agroforestry systems are discouraged whereas they play an important social role (Dumont et al., 2014; Sanial, 2015). Managing agroforestry systems in a sustainable way requires careful incentives: farmers' knowledge has to be considered. Neglecting farmers is problematical because we miss knowledge we can use for managing sustainable agroforestry systems, but also because it encourages farmers' passiveness. Moreover, associated trees shouldn't be seen in an only ecosystem's services role only: trees can also play a social, economical, cultural, medicinal or even spiritual role (Sanial, 2015).

Another strategy was cocoa certification, performed between 2006 and 2014. This certification was based on environmental and ethical standards, such as the number of trees in the plantation, and permit producers to have an income. It is then a strong incentive for promoting cocoa agroforestry (Sanial, 2015). But it's a tool that should be taken carefully: eco-certification should be used with a good support to farmers, which isn't always done (Dumont et al., 2014). Moreover, the principal motivation for farmers to apply to this certification is economical, and its ideology was therefore more production-oriented than sustainable: this logic answers more to the expectations of developed countries rather than of farmers'. Research in cocoa agroforestry should thus embrace local knowledge with cocoa agronomy and ecosystem services to achieve a sustainable production (Franzen and Borgerhoff Mulder, 2007; Dumont et al., 2014).

\section{Jungle rubber in Indonesia}

Jungle rubber is considered as the model for complex agroforestry systems. Its functioning is comparable to that of secondary forest. This system is mainly met in Indonesia, where $70 \%$ of the exported rubber came from those systems (Penot and Ollivier, 2009).
The effectiveness of these systems is mainly assessed in an environmental way. Indeed, resources in water and soil are effectively managed, and a large biological diversity is met. This complex agroforest is not the most productive, but its establishment costs are almost null, as well as the workforce needed. Moreover, in addition of the rubber which is the main income, farmers can enjoy other products made available by the forest such as fruits, medicine plants, firewood and timber wood (Gouyon et al., 1993; Penot, 2004). However, the low productivity of jungle rubber is insufficient compared to other opportunities for farmers. New agricultural systems such as cinnamon, oil palm and monocultural rubber clones and the global increase of quality of life encourages farmers to switch to these more gainful systems (Kelfoun, 1997; Penot, 2004; Rist et al., 2010).

Environmental services in these complex agroforests are therefore well recognized, but Indonesia is the only country in which they are widespread. Some research programs have been implemented since 1994 to promote these systems and to enhance better interactions: some systems are based on a mix between rubber and fruit trees and other are more adapted for the fight against some diseases and pests (Penot and Ollivier, 2009). Financial incentives such as payment for environmental services should be given in order to promote these systems against monocultural systems that are more attractive for farmers (Villamor and Van Noordwijk, 2011). Moreover, in a context where more food production is needed, an extensive and low yields vision of management cannot be dominant: jungle rubber can in this way be compared with a "pristine" vision of nature, in which human activities are absent or limited. But systems must be productive enough to be economically beneficial for farmers.

\section{Discussion}

The bibliometric analysis showed that the relative importance of environmental topics is extremely meaningful since the last two decades. We will now discuss the levels for this more and more significant recognition of environmental topics within agroforestry research.

\section{The emergence of environmental concepts in rural areas permitted the evolution of the agroforestry concept}

In parallel to this recognition of environmental issues within agroforestry, environmental concepts themselves evolved and therefore modified at the same time the agroforestry concept. Sub-topics and new sciences such as biodiversity, novel ecosystems and agroecology changed the way we consider agroforestry systems.

\section{Biodiversity is not only wild: towards a conservation of human-dominated landscapes}

Since the Rio Summit in 1992 and its Convention on Biological Diversity, biodiversity became a standard for nature conservation. Its erosion, one of the major effects of human activities, is then considered as a major challenge. The wilderness concept was incrementally replaced by that of biodiversity; and the reintegration of human in nature has permitted the abandonment of the dualistic vision of conservation, in which nature and culture were separated (Larrère and Larrère, 2015). 
Despite the extension of biodiversity as a wide scientific area and the increasing creation of national parks and reserves, biodiversity is still in rapid decline: protecting places of particular beauty or places with large number of species is therefore not sufficient (Kareiva et al., 2012). Contemporaneous conservation should therefore turn towards a new direction in which humans and their activities are involved in nature (Caillon and Degeorges, 2005; Micoud, 2005). Indeed, the consequences of human activities within the Anthropocene are proven: nature untouched by human influences doesn't exist. Human activities can therefore carry on with and within biodiversity conservation, and conservation success will depend on the people's support on conservation goals, and on the ability to discover win-win outcomes for both people and nature (Kareiva and Marnier, 2012). Biodiversity conservation should occur in the whole territory, in places such as tropical primary forests as well as human-dominated and human-altered landscapes. Agroforestry systems became therefore a ground for biodiversity conservation.

\section{The ecological interest of redesigned or constructed systems: agroforestry affiliated to novel ecosystems?}

With the reintegration of human in nature came the concept of novel ecosystems, or emerging ecosystems. They are defined as: "a system of abiotic, biotic and social components that, by virtue of human influence, differ from those that prevailed historically, having a tendency to self-organize and manifest novel qualities without intensive human management" (Hobbs et al., 2013). They result from direct human activity, environmental change or impact of introduced species (Hobbs et al., 2006; Lindenmayer et al., 2015). Their conservation value should therefore be seen within the process of evolution (Marris, 2011).

This definition of novel ecosystems seems to apply on agroecosystems and more particularly on secondary forests, plantation forests but also agroforestry systems. Indeed, those systems occur after a significant human disturbance and differ in structure and/or species composition from the nearby pristine habitats on similar sites (Van Noorwijk et al., 2016). With their new and human-influenced combinations of species, these novel ecosystems can therefore be seen as an opportunity for biodiversity conservation (Brockerhoff et al., 2008; Chazdon et al., 2009).

It is often assumed that agroecosystems have nothing more than planned biodiversity, but we do meet a lot of extremely biodiverse farmers' farming systems, especially in the tropics (Perfecto and Vandermeer, 2015). Agroforestry systems can thus be considered as biodiversity reservoirs, as they contain many native and non-native species and present a high level of complex interactions (Archarya, 2006; Six et al., 2014, Perfecto and Vandermeer, 2015). On the contrary, novel ecosystems require a management that should be adapted to the ecological and to the socio-economical regional context (Morse et al., 2014; Murcia et al., 2014). It is in this sense that agroforestry systems can be affiliated to novel ecosystems. Although agroforestry is an ancestral practice used by farmers for centuries, its functioning occurs with ecological, economical and social interactions and thus its management is comparable to what is needed for a novel ecosystem. Agroforestry systems can therefore be seen within novel ecosystems, as ecosystems that result from human activities and that present a high level of biodiversity and complex interactions.

\section{Progressive recognition of agroecology as a science}

The concept of agroecology first appeared in the 1930s, it was defined as the application of ecology in agriculture (Wezel et al., 2009). It became the science of agroecosystems in the early 1980s, and consolidated as it in the next decade (Wezel and Soldat, 2009). In the last two decades, the agroecological science incorporated new dimensions and became more and more significant in research. A more systemic approach is promoted: agroecology is not anymore limited to the main domains of agriculture and ecology. It includes all the scales of a food system and involves new topics such as biodiversity, sociology and politics, toward the core subject of sustainable agriculture (Wezel and Soldat, 2009; Tomich et al., 2011; Méndez et al., 2013).

As we have seen above, environmental topics had almost the same evolution in agroecological and agroforestry research since the last two decades. Agroforestry could therefore be seen within agroecology, as a science, a technique and a practice for managing sustainable food systems. Both sciences include indeed not only agricultural and environmental topics, but also socio-economical topics (Schroth et al., 2004; Wezel et al., 2009). Although the share of socio-economical topics is not that huge it is still there and is part of a food system. The last two decades were crucial for the advent of a conservation science that can occur in agricultural landscapes, and for the emergence of a sustainable science and practice for managing those systems.

\section{Is this evolution of environmental topics within agroforestry research effective for farmers?}

\section{Where is the farmer interest (or not) in this new vision of agroforestry?}

This new vision of agroforestry in which environmental topics are increasingly meaningful is beneficial for farmers in the sense that a better understanding of ecological interactions and environmental services will help to design sustainable agroforestry systems. However, in the light of the examples developed in above, we can distinguish several limits that have to be taken into account.

Agroforestry projects must be realized according to the expectations of farmers: It is often the farmers who decide to change their ancestral practices to more intensive ones. We must abandon the assumption that farmers will welcome the preservation of their traditional livelihood systems if it's not beneficial for them (Garcia et al., 2009). We must understand their will of increased income and establish sustainable systems that can answer to their wishes.

Socio-economical and political factors enhance the environmental ones: The definition of agroforestry involves social and economical topics in the design of sustainable food systems. In practice it appears that these components are often leftovers. Social economical and political aspects 
are the drivers of most decision makings, and neglecting them will obligatory lead to a failure in the design and the management of sustainable food systems.

Management and incentive tools should be taken carefully: Certification as an economic incentive can indeed be a way to promote agroforestry systems, but its use should evolve to be a real tool for sustainability (Ruf et al., 2014). Moreover, certifications should take into account the cultural differentiation in the nature of maintained trees: they cannot all be used to enhance ecosystem services (Sanial, 2015).

Production-oriented systems are hardly sustainable: Promoting exotic trees known for their environmental value lead to a standardization of agroforestry systems, which tend to production-oriented systems. This is disastrous not only for biodiversity but also in a social and cultural way (Garcia et al., 2009; Rist et al., 2010; Sanial, 2015). An increased production is of course one of the goals of agroforestry systems, but it shouldn't be done at the expense of social aspects.

\section{How does research follow this evolution?}

Our bibliometric analysis showed that - whereas the global share of environmental topics in agroforestry research is important - application of this research for farmers seems generally quite low (figure 5). However, we did not identify areas in which there is a significant lack of research or areas that are over-represented.

The evolution of the agroforestry concept, which was enriched with environmental topics and concepts, is presumably too disconnected from the field reality in research. Perhaps a research in a more participatory form with the farmers should be encouraged and developed, in order to embrace at the same time local knowledge, agronomy and ecosystem services provision. Moreover, the bibliographical analysis did not permit to meet studies about the durability of agroforestry systems.

\section{Conclusion}

The incorporation of environmental topics and concepts resulted in a significant evolution of the agroforestry concept. Agroforestry is now seen as an entire environment-friendly food system and applies the principles of agroecology. Agroforestry systems provide a wide variety of ecosystem services and are a ground for biodiversity conservation.

Whereas the incorporation and the application of environmental sciences are necessary for the management of sustainable agroforestry systems, this evolution may have been done at the expense of farmers who became passive and puzzled in front of the conception of new agroforestry systems. Farmers' expectations may be devaluated in this new vision of agroforestry. While research should be done for the benefit of farmers, only $20 \%$ of the total studies on agroforestry indexed in the Web of Science contain the word "smallholder" or "farmer". By analysing the examples of coffee agroforestry systems in Western Ghats in India, cocoa agroforestry in Côte d'Ivoire and jungle rubber in Indonesia, we clearly see false notes in their management. The integration of environmental concerns in elaborating agroforestry projects is indeed often made without considering the farmers' expectations, and the socio-economical and political factors are often neglected. Moreover, advices and tools promoted in these projects, such as exotic species and eco-certification, should be better used.

This new regard on agroforestry systems seems to be finally a little disconnected from the food production: its evolution is more and more theoretical, and even more somewhat ideological. The evolution of the concept is widely known, but their applications are less obvious. Research should perhaps turn towards more practical studies which mustn't forget farmers' knowledge, in order to give them a framework to manage their agroforestry systems in a sustainable way.

\section{Acknowledgements}

This work has been supported by Bois et Forêts des Tropiques, within a two months training course. I am grateful to many experts from Cirad for stimulating discussions about aspects of this paper, especially, Elsa Sanial, François Ruf, Claude Garcia, Régis Peltier, Philippe Bastide, Olivier Sounigou, Dominique Louppe, Nicole Sibelet and Jacques Tassin. The paper has been improved from the constructive comments of three anonymous reviewers.

\section{References}

Ambinakudige S., Sathish B. N., 2008. Comparing tree diversity and composition in coffee farms and sacred forests in the Western Ghats of India. Biodiversity Conservation, 18: 987-1000. http://dx.doi.org/10.1007/s10531-008-9502-5

Anand M. O., Krishnaswamy J., Kumar A., Bali A., 2010. Sustaining biodiversity conservation in human-modified landscapes in the Western Ghats: Remnant forests matters. Biological Conservation, 143: 2363-2374. http://dx.doi. org/10.1016/j.biocon.2010.01.013

Archarya K. P., 2006. Linking trees on farms with biodiversity conservation subsistence farming systems in Nepal. Biodiversity and Conservation, 15: 631-646. http://dx.doi. org/10.1007/s10531-005-2091-7

Bene J. G., Beall H. W., Cote A., 1977. Trees, food and people: land management in the tropics. International Development Research Centre, Ottawa, Canada. http://hdl.handle. net/10625/930

Brockerhoff E. G., Jactel H., Parrotta J. A., Quine C. P., Sayer J., 2008. Plantation forests and biodiversity: oxymoron or opportunity? Biodiversity and Conservation, 17: 925-951. http://dx.doi.org/10.1007/s10531-008-9380-x 
Caillon S., Degeorges P., 2005. Biodiversité(s), quand les frontières entre nature et culture s'effacent. La biodiversité est-elle encore naturelle ? Écologie et politique, 30 : 85-95. http://www.ecologie-et-politique.info/IMG/pdf/30-Biodiversite-s-quand-les-frontieres-entre-culture-et-nature-s-effacent.pdf

Chazdon R. L., Peres C. A., Dent D., Sheil D., Lugo A. E., Lamb D., Stork N. E., Miller S. E., 2009. The potential for species conservation in tropical secondary forests. Conservation Biology, 23: 1406-1417. http://dx.doi. org/10.1111/i.1523-1739.2009.01338.x

Duguma B., Gockowski J., Bakala J., 2001. Smallholder Cacao (Theobroma cacao Linn.) cultivation in agroforestry systems of West and Central Africa: challenges and opportunities. Agroforestry Systems, 51: 177-188. http://dx.doi. org/10.1023/A:1010747224249

Dumont E. S., Gnahoua G. M., Ohouo L., Sinclair F. L., Vaast P., 2014. Farmers in Côte d'Ivoire value integrating tree diversity in cocoa for the provision of ecosystem services. Agroforestry Systems, 88: 1047-1066. http://dx.doi.org/10.1007/ s10457-014-9679-4

Franzen M., Borgerhoff Mulder M., 2007. Ecological, economic and social perspectives on cocoa production worldwide. Biodiversity Conservation, 16: 3835-3849. http://dx.doi. org/10.1007/s10531-007-9183-5

Garcia C. A., Marie-Vivien D., Kushalappa C. G., Chengappa P. G., Nanaya K. M., 2007. Geographical indications and biodiversity in the Western Ghats, India: can labeling benefit producers and the environment in a mountain agroforestry landscape? Mountain Research and Development, 27 (3): 206-210. http://dx.doi.org/10.1659/mrd.0922

Garcia C. A., Bhagwat S. A., Ghazoul J., Nath C. D., Nanaya K. M., Kushalappa C. G., et al., 2009. Biodiversity conservation in agricultural landscapes: challenges and opportunities of coffee agroforests in the Western Ghats, India. Conservation Biology, 24 (2): 479-488. http://dx.doi. org/10.1111/i.1523-1739.2009.01386.x

Gouyon H., De Foresta H., Levang P., 1993. Does “jungle rubber" deserve its name? An analysis of rubber agroforestry systems in southeast Sumatra. Agroforestry Systems, 22: 181-206. http://dx.doi.org/10.1007/BF00705233

Harvey C. A., Komar O., Chazdon R., Ferguson B. G., Finegan B., Griffith D. M., et al., 2008. Integrating agricultural landscapes with biodiversity conservation in the Mesoamerican hotspot. Conservation Biology, 22 (1): 8-15. http://dx.doi. org/10.1111/i.1523-1739.2007.00863.x

Hobbs R. J., Arico S., Aronson J., Baron J. S., Bridgewater P., Cramer V. A., et al., 2006. Novel ecosystems: theoretical and management aspects of the new ecological world order. Global Ecology and Biogeography, 15: 1-7. http://dx.doi. org/10.1111/i.1466-822X.2006.00212.X

Hobbs R. J., Higgs E. S., Hall C. M., 2013. Defining novel ecosystems. Novel Ecosystems: intervening in the new ecological world order. John Willey \& Sons Ltd, 380 p.
Jose S., 2009. Agroforestry for ecosystem services and environmental benefits: an overview. Agroforestry systems, 76 (1): 1-10. http://dx.doi.org/10.1007/s10457-009-9229-7

Kareiva P., Marvier M., 2012. What is conservation science? BioScience, 62: 962-969. http://dx.doi.org/10.1525/ bio.2012.62.11.5

Kareiva P., Marvier M., Lalasz R., 2012. Conservation in the Anthropocene. Beyond solitude and fragility. The Breakthrough Institute. http://thebreakthrough.org/index.php/journal/past-issues/issue-2/ conservation-in-the-anthropocene

Kelfoun A., 1997. La nécessaire évolution des agroforêts à hévéas pour une meilleure productivité : contraintes et opportunités dans la province de Jambi, Sumatra, Indonésie. France, Rennes, ENSAR, 65 p. http://agritrop.cirad. fr/546292/

Kushalappa C. G., Vaast P., Raghuramulu Y., Garcia C., Sinclair F. L., 2014. CAFNET - First effort in India to value ecosystem services from coffee based agroforestry systems. In: Abstracts of the 3rd World Congress of Agroforestry, Compendium of abstracts, Trees for life: accelerating the impact of agroforestry, Eds Wachira M. A., Rabar B., Magaju C., Borah G., Nairobi, World Agroforestry Center, p. 2. http://www.worldagroforestry.org/downloads/Publications/PDFS/B17335.PDF

Larrère C., Larrère R., 2015. Penser et agir avec la nature. France, Éditions La Découverte : 334 p.

Lindenmayer D., Messier C., Paquette A., Hobbs R. J., 2015. Managing tree plantations as novel socioecological systems: Australian and North American perspectives. Canadian Journal of Forest Research, 45: 1527-1433. http:// dx.doi.org/10.1139/cjfr-2015-0072

Lundgren B., Raintree J. B., 1983. Sustained Agroforestry. Agricultural research for development: potentials and challenges in Asia. Jakarta (Indonesia). Reprinted from Agricultural Research for Development: Potentials and Challenges in Asia, report of a conference, Jakarta, Indonesia, October 24-29 1982, Ed. Nestel B. The Hague, ISNAR, 1983, ICRAF, 27 p. http://pdf.usaid.gov/pdf docs/PNABC621.pdf Marie-Vivien D., Garcia C. A., Kushalappa C. G., Vaast P., 2014. Trademarks, geographical indications and environmental labeling to promote biodiversity: the case of agroforestry coffee in India. Development Policy Review, 32 (4): 379-398. http://dx.doi.org/10.1111/dpr.12060

Marris E., 2011. Rambunctious garden: saving nature in a post-wild world. USA, Bloomsbury, $210 \mathrm{p}$.

Méndez V. E., Bacon C. M., Cohen R., 2013. Agroecology as a transdisciplinary, participatory and action-oriented approach. Agroecology and Sustainable Food Systems, 37 (1): 3-18. http://dx.doi.org/10.1080/10440046.2012.736926

Micoud A., 2005. La biodiversité est-elle encore naturelle? Écologie et Politique, 30 : 17-25. http://www.ecologie-et-politique.info/IMG/pdf/30-La-biodiversite-est-elle-encore-naturelle.pdf 
Morse N. B., Pellissier P. A., Cianciola E. N., Brereton R. L., Sullivan M. M., Shonka N. K., Wheeler T. B., McDowell W. H., 2014. Novel ecosystems in the Anthropocene: a revision of the novel ecosystem concept for pragmatic applications. Ecology and Society, 19 (2): 12. http://dx.doi.org/10.5751/ ES-06192-190212

Murcia C., Aronson J., Kattan G. H., Moreno-Mateos D., Dixon K., Simberloff D., 2014. A critique of the "novel ecosystem" concept. Trends in Ecology \& Evolution, 29 (10): 548-553. http://dx.doi.org/10.1016/j.tree.2014.07.006

Penot E., 2004. From shifting agriculture to sustainable rubber agroforestry systems (jungle rubber) in Indonesia: a history of innovations processes. In: Beyond tropical deforestation, Ed. Babin D., UNESCO/Cirad, 221-250. https://hal. archives-ouvertes.fr/file/index/docid/173302/filename/ BOOK CHAPTER unesco 2003 af_pENOT.pdf

Penot E., Ollivier I., 2009. L'hévéa en association avec les cultures pérennes, fruitières ou forestières: quelques exemples en Asie, Afrique et Amérique latine. Bois et Forêts des Tropiques, 301 (3): 67-82. http://bft.cirad.fr/cd/ BFT 301 67-82.pdf

Perfecto L., Vandermeer J., 2008. Biodiversity conservation in tropical agroecosystems. The Year in Ecology and Conservation Biology, 173-200. http://dx.doi.org/10.1196/ annals.1439.011

Perfecto I., Vandermeer J., 2015. Structural constraints on novel ecosystems in agriculture: The rapid emergence of stereotypic modules. Perspectives in Plant Ecology, Evolution and Systematics, 17 (6): 522-530. http://dx.doi. org/10.1016/j.ppees.2015.09.002

Rist L., Feintrenie L., Levang P., 2010. The livelihood impacts of oil palm: smallholders in Indonesia. Biodiversity and Conservation, 19 (4): 1009-1024. http://dx.doi. org/10.1007/s10531-010-9815-z

Ruf F., 1997. Booms et crises du cacao. Économie Rurale, 239 (1) : 61-62. http://www.persee.fr/doc/ecoru 001305591997 num 23914869 t1 006100001

Ruf F., N’Dao Y., Lemeilleur S., 2014. Certification du cacao, stratégie à hauts risques. Bulletin de Veille Inter-réseaux Développement Rural, 217 : 1-7. http://www.inter-reseaux. org/IMG/pdf/Certification du cacao Ruf juin2013.pdf

Sanial E., 2015. À la recherche de l'ombre: analyse du retour des arbres associés dans les plantations de cacao ivoiriennes. Master II, Université Jean Moulin Lyon 3.

Schroth G., da Fonseca G. A. B., Harvey C. A., Gascon C., Vasconcelos H. L., Izac A. M., 2004. Agroforestry and Biodiversity Conservation in Tropical Landscapes, Washington DC, Island Press, 524 p. http://library.uniteddiversity.coop/ Permaculture/Agroforestry/Agroforestry and Biodiversity Conservation in Tropical Landscapes.pdf

Six L. J., Bakker J. D., Bilby R. E., 2014. Vegetation dynamics in a novel ecosystem: agroforestry effects on grassland vegetation in Uruguay. Ecosphere, 5: 1-15. http://dx.doi. org/10.1890/ES13-00347.1
Tomich T. P., Brodt S., Ferris H., Galt R., Horwath W. R., Kebreab E., et al., 2011. Agroecology: a review from a global-change perspective. Annual Review of Environment and Resources, 36: 193-222. http://dx.doi.org/10.1146/ annurev-environ-012110-121302

Van Noorwijk N., Coe R., Sinclair F., 2016. Central hypotheses for the third agroforestry paradigm within a common definition. Working Paper 223, Bogor, Indonesia: World Agroforestry Centre (ICRAF), Southeast Asia Regional Program.

Villamor G. B., Van Noordwijk M., 2011. Social role-play games vs individual perceptions of conservation and PES agreements for maintaining rubber agroforests in Jambi (Sumatra), Indonesia. Ecology and Society, 16 (3): 27. http://dx.doi.org/10.5751/ES-04339-160327

Wezel A., Bellon S., Doré T., Francis C., Vallod D., 2009. Agroecology as a science, a movement and a practice. A review. Agronomy for Sustainable Development, Springer Verlag/EDP Sciences/INRA, 2009, 29 (4): 503-515. http:// dx.doi.org/10.1051/agro/2009004

Wezel A., Soldat V., 2009. A quantitative and qualitative historical analysis of the scientific discipline of agroecology. International Journal of Agricultural Sustainability, 7 (1): 3-18. http://dx.doi.org/10.3763/ijas.2009.0400 